\title{
Research Article \\ EFFECT OF DIFFERENT COMBINATIONS OF NUTRIENT SOURCES AND WEEDING PRACTICE ON THE PHYSIOLOGICAL CHARACTERS OF RAPESEED IN HUMID SUBTROPICAL CONDITION OF CHITWAN
}

\author{
K. B. Basnet \\ Institute of Agriculture and Animal Sciences, Rampur, Chitwan, Nepal
}

\begin{abstract}
A field experiment was conducted during the winter season of 2001-2002 at Mangalpur, Chitwan, Nepal to evaluate the performance of rapeseed in different agronomic management practices. The experiment was conducted with 16 treatments in a randomized complete block design (RCBD) with three replications. The treatments included control without input and four agronomic inputs (NPK, FYM, micronutrient- Zn, B and $\mathrm{S}$ and weeding), six and four combinations of two and three inputs respectively and a full package with all inputs. Application of NPK fertilizers increased leaf area and total dry matter per plant significantly as compared to control and weeding practice at 55 and 40 DAS, respectively. Further, in two factor combinations, significantly higher leaf area and particularly total dry matter per plant was produced by the application of NPK fertilizers with FYM at all stages (25 to 85 DAS) of growth and development. Finally, exclusion of NPK fertilizers in the combination of three agronomic inputs significantly lowered leaf area and total dry matter per plant as compared to others which included it at 40 and 70 DAS. All above mentioned trends were reflected on rapeseed yield indicating its significant correlation with leaf area $(r=0.971)$ and total dry matter per plant $(r=0.976)$. In general, addition of NPK fertilizers to other combinations of agronomic inputs increased leaf area and total dry matter per plant significantly.
\end{abstract}

Key words: Leaf area, dry matter, agronomic inputs, yield

\section{INTRODUCTION}

Rapeseed (Brassica campestris var. toria) is an important oilseed crop of the Asian continent. India and China are the two major countries in terms of area and production of this crop (Rathore, 1999). Oilseed is one of the important cash crops of Nepal. It occupied 0.18 million hectares of land with the production of 0.11 million tonnes and productivity of $609 \mathrm{~kg} / \mathrm{ha}$ in 1997/98 (Mishra, 2000). Among oilseed crops, rapeseed (Brassica campestris var toria) is a dominant crop of Nepal. Its cultivation has occupied about $85 \%$ of the total oilseed area in the country. It is mostly grown after monsoon maize in upland condition and after early rice in lowland of terai, inner terai and mid-hills (Ghimire et al., 2000). The production of rapeseed has been declining for last some few years in the country (Chaudhary et al., 1993, Sribastava and Neupane, 2000). It is because of this reason, Nepal is importing oilseeds to meet the domestic demand at the cost of hard currency. In 1997/98, Nepal imported huge quantities of edible and non-edible oils to the tune of NRs 1544.6 million (Annual Report, 1998/99).

Different factors like improper fertilization and weed management (Chaudhary et al., 1993), micronutrient deficiencies, rainfed growing condition and poor plant population are considered as the reasons of low yield of rapeseed (Kumar, 1989). These factors influence on the physiological basis of yield. The first physiological basis for high yield is a high production of total dry matter per unit area. The amounts of dry matter produced depend on the effectiveness of photosynthesis of the crop which in its turn is dependent on assimilating area. Finally, the manner in which the net dry matter produced is distributed among the different parts of the plant will determine the magnitude of the economic yield (Arnon, 1972; Reddy and Reddi, 1997). So, this experiment was designed to assess the effect of different sources of nutrition and weeding and their combinations on the formation of assimilating area and production of dry matter in the humid sub-tropical condition of Chitwan.

\section{MATERIALS AND METHODS}

This experiment was conducted during the winter season of 2001-2002 at Mangalpur village development committee, Chitwan in upland condition after sesame (Sesamum indicum L.). The soil analysis of the experimental 
field at a depth of $0-15 \mathrm{~cm}$ showed sandy loam in texture with moderately acidic in reaction ( $\mathrm{pH}$ 5.5). Moreover, it was low in total nitrogen $(0.09 \%)$ content, high in available phosphorus $(87.5 \mathrm{~kg} / \mathrm{ha})$ and medium in potassium (145 kg/ha). Randomized complete block design (RCBD) with three replications was used. There was one control (without input). The micronutrients containing zinc (10 kg/ha), boron (2 kg/ha) and sulphur (25 kg/ ha), weedings at 20 and 40 days after sowing, NPK fertilizers@60:40:20 kg/ha and FYM @12 t/ha were the single factor inputs tested separately. Besides these treatments, six combinations of two inputs (FYM and weeding, weeding and NPK fertilizers, weeding and micronutrient, FYM and NPK fertilizers, FYM and micronutrient, NPK fertilizers and micronutrient) and four combinations of three inputs (FYM + weeding + NPK fertilizers, FYM + weeding + micronutrient, FYM + micronutrient + NPK fertilizers, NPK fertilizers + micronutrient + weeding) were arranged respectively. The full package treatment included all four inputs (NPK, FYM, weeding and micronutrients). In this way 16 treatments were formed to evaluate their effects on leaf area and total dry matter per plant. Treatment combinations are illustrated in the Table 1 and 2.

The rapeseed crop was sown on $2^{\text {nd }}$ November 2001. The plot size was $10.8 \mathrm{~m}^{2}$ for each treatment. Crop was sown maintaining a row to row distance of $30 \mathrm{~cm}$ and plant to plant of $5 \mathrm{~cm}$. Thus, 60 plants were maintained in each row. FYM (farm yard manure) was applied 15 days before seeding. Chemical fertilizers as a basal dressing were applied in the furrows opened at a depth of $8-10 \mathrm{~cm}$ at sowing. Three scheduled sprays of insecticide (Thiodan 35 EC @ 2 ml/liter of water) and fungicide (Bavistin 50 WP@ 2 gm/liter water) were applied at an interval of 15 days starting from the 25 days after seeding (DAS) to control the aphid and alternaria blight of rapeseed. The crop grown in the experiment received $86.6 \mathrm{~mm}$ precipitations in total. Chitwan local cultivar was sown in the experiment at the rate of $10 \mathrm{~kg}$ per hectare. Leaf area was measured on 10 plants at an interval of 15 days from 25 to 70 DAS. Total dry matter of the plants was calculated from the same 10 plants by drying at the temperature of $70^{\circ} \mathrm{C}$ in the electric oven. Due to drying and shedding of leaves, leaf area per plant was measured up to 70 DAS, but total dry weight was taken up to 85 DAS. Duncan's multiple range test (DMRT) was used to separate means. MSTATC 1997 was the computer software used to analyze the data.

\section{RESULTS AND DISCUSSION}

\section{Leaf area (LA)}

The average data of leaf area per plant (LAP) of rapeseed crop indicates that it increased up to the stage of siliqua formation (40 DAS) and then gradually declined (Table 1). Such trend was observed in all treatments except in separate application of NPK fertilizers, FYM and full package where LAP was continuously increased up to the intensive growth stage of siliqua (55 DAS). This was due to the fact that both (NPK and FYM) are the main sources of nutrition, which assist to increase vegetative growth and delay leaf senescence.

Thus, at the stage of intensive growth and development of siliqua (55 DAS), application of NPK fertilizers increased LAP $\left(84.83 \mathrm{~cm}^{2}\right)$ significantly as compared to control $\left(34.13 \mathrm{~cm}^{2}\right)$ and weeding $\left(37.8 \mathrm{~cm}^{2}\right)$ treatments. The same trend was observed in yield. The yield $(490.8 \mathrm{~kg} / \mathrm{ha})$ obtained due to NPK fertilizer application was significantly higher than control $(254.6 \mathrm{~kg} / \mathrm{ha}$ ) and weeding $(213.0 \mathrm{~kg} / \mathrm{ha})$ treatments (Basnet et al., 2004).

Further, higher leaf area per plant was recorded in the combination of FYM and NPK fertilizers at all stages (25 to 70 DAS) of growth and development. Application of micronutrient in combination with NPK fertilizers was effective for the increment in leaf area per plant at the later stages of growth and development. This was very obvious at the beginning of maturation (70 DAS) where the higher leaf area $\left(44.37 \mathrm{~cm}^{2}\right)$ per plant retained in the combination of NPK fertilizers with FYM was only insignificant to NPK fertilizers and micronutrient $\left(42.13 \mathrm{~cm}^{2}\right)$ applied together. The similar trend was observed in yield. The higher yield (657.4 kg/ ha) produced by the application of NPK fertilizers and FYM was insignificant only to the combination of NPK fertilizers and micronutrient (578.7 kg/ha) (Basnet et al., 2004). Moreover, the higher leaf area per plant retained at 70 DAS in the combination of NPK fertilizers either with FYM or micronutrient was only insignificant to NPK fertilizers. Such trend was also observed in yield (Basnet et al., 2004). 
Table 1. Effect of different agronomic inputs and their combinations on leaf area $\left(\mathrm{cm}^{2}\right)$ per plant of rapeseed (Brassica campestris var. toria)

\begin{tabular}{|c|c|c|c|c|c|}
\hline \multirow[t]{2}{*}{ SN } & \multirow[t]{2}{*}{ Treatments } & \multicolumn{4}{|c|}{ Days after sowing (DAS) } \\
\hline & & 25 & 40 & 55 & 70 \\
\hline 1 & Control (C) & $28.73^{e}$ & $40.23^{d}$ & $34.13^{\mathrm{f}}$ & $8.83 \mathrm{~g}$ \\
\hline 2 & $\mathrm{Zn}, \mathrm{B}, \mathrm{S}(\mathrm{M})$ & $32.8 \mathrm{de}$ & $61.6^{\mathrm{cd}}$ & $55.63 \mathrm{df}$ & $17.4^{\mathrm{fg}}$ \\
\hline 3 & Weeding (W) & $28.47^{\mathrm{e}}$ & $46.5^{\mathrm{cd}}$ & $37.8^{\text {ef }}$ & $13.53^{\mathrm{g}}$ \\
\hline 4 & $\mathrm{NPK}(\mathrm{F})$ & 44.07 be & $78.0 \mathrm{bd}$ & 84.83 bd & $35.8^{\mathrm{cd}}$ \\
\hline 5 & FYM & 36.27 ce & $61.33^{\mathrm{cd}}$ & $63.83^{\mathrm{cf}}$ & $14.27^{\mathrm{g}}$ \\
\hline 6 & $\mathrm{FYM}+\mathrm{W}$ & 35.73 ce & 80.47 bd & 74.87 be & 30.57 de \\
\hline 7 & $\mathrm{~W}+\mathrm{F}$ & 48.33 ad & $82.5^{b c}$ & $51.1 \mathrm{df}$ & $25.5^{\text {ef }}$ \\
\hline 8 & $\mathrm{~W}+\mathrm{M}$ & 37.83 ce & $56.33^{\mathrm{cd}}$ & $52.3 \mathrm{df}$ & $17.97 \mathrm{fg}$ \\
\hline 9 & $\mathrm{FYM}+\mathrm{F}$ & $64.37^{a}$ & $115.5^{\mathrm{ab}}$ & $95.73 \mathrm{bc}$ & $44.37 \mathrm{bc}$ \\
\hline 10 & $\mathrm{FYM}+\mathrm{M}$ & 43.07 be & $79.0^{\text {bd }}$ & $55.43 \mathrm{df}$ & $13.13^{\mathrm{g}}$ \\
\hline 11 & $\mathrm{~F}+\mathrm{M}$ & $36.4^{\mathrm{ce}}$ & $104.0^{\mathrm{ab}}$ & $87.6^{\mathrm{bd}}$ & $42.13^{b c}$ \\
\hline 12 & $\mathrm{FYM}+\mathrm{W}+\mathrm{F}$ & $55.93 \mathrm{ab}$ & $133.2^{\mathrm{a}}$ & $93.3^{b c}$ & $62.67^{\mathrm{a}}$ \\
\hline 13 & $\mathrm{FYM}+\mathrm{W}+\mathrm{M}$ & 38.17 ce & $77.87 \mathrm{bd}$ & $67.37 \mathrm{cf}$ & $30.57 \mathrm{de}$ \\
\hline 14 & $\mathrm{FYM}+\mathrm{M}+\mathrm{F}$ & $51.0^{\mathrm{ac}}$ & $129.6^{\mathrm{a}}$ & $106.9^{\mathrm{b}}$ & $42.87^{b c}$ \\
\hline 15 & $F+M+W$ & $47.97 \mathrm{ad}$ & $141.3^{a}$ & $100.0^{b c}$ & $60.93^{a}$ \\
\hline \multirow[t]{4}{*}{16} & $\mathrm{FYM}+\mathrm{F}+\mathrm{W}+\mathrm{M}$ & $64.63^{a}$ & $135.9^{a}$ & $149.1^{\mathrm{a}}$ & $50.97^{b}$ \\
\hline & Grand Mean & 43.4 & 88.96 & 75.62 & 31.97 \\
\hline & C.V. $(\%)$ & 20.64 & 24.16 & 26.05 & 16.42 \\
\hline & SEM & 5.167 & 12.407 & 11.374 & 3.030 \\
\hline
\end{tabular}

Control - without input; Micronutrient - Zn, B and S@10, 2 and 25 kg/ha, respectively; NPK - @ 60:40:20 kg/ha; FYM - @12 t/ha

Moreover, addition of NPK fertilizers to other agronomic inputs like micronutrient, FYM and weeding practice increased leaf area per plant significantly at 70 DAS. On the other hand, addition of micronutrients, FYM and weeding practice to NPK fertilizers could not increase leaf area per plant significantly. The same trend was reflected on yield. The yield significantly increased when NPK fertilizers were added to these inputs but the difference was insignificant when they were added to it in the combinations of two inputs.

In the combinations of three inputs higher leaf area per plant was recorded at the stage of siliqua formation (40 DAS). At this stage significantly lower $\left(77.87 \mathrm{~cm}^{2}\right)$ leaf area per plant was measured in the treatment without NPK fertilizers as compared to those which included it. The treatments with NPK fertilizers were statistically at par with each other. They were also at par with full package (FYM + NPK + micronutrient + weeding). The similar trend was observed in yield (Basnet et al., 2004). Moreover, addition of NPK fertilizers to the combinations of other two inputs increased leaf area per plant significantly at 40 and 70 DAS which also helped to increase rapeseed yield significantly. Thus, it is obvious that NPK fertilizers were the major source of nutrients or factor influencing significantly on the formation of assimilating surface and yield of rapeseed crop. This result was in close conformity with the findings of Joarrder et al. (1959) in brassica crops. The correlation between LAP and yield was also significant $(\mathrm{r}=0.971)$.

\section{Total dry matter per plant}

The effect of different agronomic inputs (FYM, micronutrients, NPK fertilizers and weeding practice) on total dry matter production of the rapeseed plants (leaves, stem and siliqua together) was significant from 40 to 70 DAS only. Thus, at the beginning of siliqua formation (40 DAS) the higher dry matter $(0.792 \mathrm{~g} / \mathrm{plant})$ accumulated in the plants with the application of NPK fertilizers was significant over control and weeding practice but at par with other sources of nutrients (FYM and M). Similar trend was observed in rapeseed yield. The yield $(490.8 \mathrm{~kg} / \mathrm{ha}$ ) obtained with NPK fertilizers application alone was significantly higher than control $(254.6 \mathrm{~kg} / \mathrm{ha}$ ) and weeding practice $(213.0 \mathrm{~kg} / \mathrm{ha}$ ) only (Basnet et al., 2004). Application of NPK (Kumar, 2001), FYM (Bhatia and Sukla, 1982) and zinc, boron, sulphur (Kumar and Singh, 1984) to the rapeseed and mustard was reported to increase seed yield. Remarkably higher dry matter per plant produced by the application of NPK fertilizers was significant to control and weeding practice at all stages (from 40 to 70 DAS). 
Table 2. Effect of different agronomic inputs and their combinations on the production of total dry matter $(\mathrm{g} / \mathrm{plant})$ per plant of rapeseed (Brassica campestris var. toria)

\begin{tabular}{|c|c|c|c|c|c|c|}
\hline \multirow[t]{2}{*}{ SN } & \multirow[t]{2}{*}{ Treatments } & \multicolumn{5}{|c|}{ Days after sowing (DAS) } \\
\hline & & 25 & 40 & 55 & 70 & 85 \\
\hline 1 & Control (C) & $0.126^{\mathrm{fg}}$ & $0.418^{g}$ & $0.984 \mathrm{gh}$ & $1.093 \mathrm{~g}$ & $1.436^{\mathrm{e}}$ \\
\hline 2 & $\mathrm{Zn}, \mathrm{B}, \mathrm{S}(\mathrm{M})$ & $0.146^{\mathrm{eg}}$ & $0.656^{\text {ef }}$ & $1.192^{\mathrm{fg}}$ & $1.612^{\mathrm{f}}$ & $1.821^{\mathrm{e}}$ \\
\hline 3 & Weeding (W) & $0.110^{g}$ & $0.467^{g}$ & $0.827^{\mathrm{h}}$ & $1.141^{\mathrm{g}}$ & $1.378^{\mathrm{e}}$ \\
\hline 4 & $\mathrm{NPK}(\mathrm{F})$ & $0.215^{\mathrm{cg}}$ & $0.792^{\mathrm{cg}}$ & $1.794^{\mathrm{cd}}$ & $2.902^{c}$ & 2.565 be \\
\hline 5 & FYM & $0.194^{\mathrm{cg}}$ & 0.756 de & 1.616 de & $1.718^{\text {ef }}$ & $1.750^{\mathrm{e}}$ \\
\hline 6 & $\mathrm{FYM}+\mathrm{W}$ & $0.152^{\mathrm{dg}}$ & 0.840 be & 1.628 de & $2.218^{\mathrm{d}}$ & $1.973 \mathrm{de}$ \\
\hline 7 & $W+F$ & $0.236^{b f}$ & $0.964^{\mathrm{bc}}$ & $1.658 \mathrm{de}$ & $2.219^{\mathrm{d}}$ & $2.168^{\text {ce }}$ \\
\hline 8 & $\mathrm{~W}+\mathrm{M}$ & $0.163 \mathrm{dg}$ & $0.536^{\mathrm{fg}}$ & $1.057^{\mathrm{gh}}$ & $1.217^{g}$ & $1.519^{\mathrm{e}}$ \\
\hline 9 & $\mathrm{FYM}+\mathrm{F}$ & $0.721^{a}$ & $1.311^{\mathrm{a}}$ & $2.427^{\mathrm{b}}$ & $4.254^{a}$ & $3.719 \mathrm{ab}$ \\
\hline 10 & $\mathrm{FYM}+\mathrm{M}$ & 0.242 be & 0.855 bd & $1.51 \mathrm{de}$ & $1.806 \mathrm{df}$ & $2.183^{\text {ce }}$ \\
\hline 11 & $\mathrm{~F}+\mathrm{M}$ & $0.164^{\mathrm{dg}}$ & $0.988^{\mathrm{b}}$ & $1.636 \mathrm{de}$ & $2.948^{b c}$ & 3.449 ac \\
\hline 12 & $\mathrm{FYM}+\mathrm{W}+\mathrm{F}$ & $0.286^{b c}$ & $1.354^{\mathrm{a}}$ & $2.411^{b}$ & $4.222^{a}$ & $3.284^{\mathrm{ad}}$ \\
\hline 13 & $\mathrm{FYM}+\mathrm{W}+\mathrm{M}$ & $0.177 \mathrm{dg}$ & 0.766 de & $1.457^{\mathrm{ef}}$ & $2.095^{\mathrm{de}}$ & 1.998 de \\
\hline 14 & $\mathrm{FYM}+\mathrm{M}+\mathrm{F}$ & $0.255^{\text {bd }}$ & $1.390^{\mathrm{a}}$ & $2.517^{\mathrm{b}}$ & $4.465^{a}$ & $4.301^{a}$ \\
\hline 15 & $\mathrm{~F}+\mathrm{M}+\mathrm{W}$ & 0.250 be & $1.294^{\mathrm{a}}$ & $2.036^{\mathrm{c}}$ & $3.147 \mathrm{bc}$ & $3.769^{\mathrm{ab}}$ \\
\hline \multirow[t]{3}{*}{16} & $\mathrm{FYM}+\mathrm{F}+\mathrm{W}+\mathrm{M}$ & $0.321^{\mathrm{b}}$ & $1.392^{\mathrm{a}}$ & $2.901^{\mathrm{a}}$ & $3.347^{\mathrm{b}}$ & $4.244^{a}$ \\
\hline & Grand Mean & 0.235 & 0.924 & 1.728 & 2.525 & 2.597 \\
\hline & SEM & 0.032 & 0.060 & 0.102 & 0.135 & 0.407 \\
\hline
\end{tabular}

Control - without input; Micronutrient - Zn, B and S@10,2 and 25 kg/ha, respectively; NPK - @ 60:40:20 kg/ha; FYM - @12 t/ha

Further, significantly higher dry matter was accumulated in rapeseed plants by the application of NPK fertilizers and FYM at all stages of growth and development (25 to 70 DAS). Even at 85 DAS, it was insignificant only to the combination of NPK fertilizers and micronutrient. Similar effect was reflected in yield (Basnet et al., 2004). In all two factor combinations of weeding practice ( $W+F Y M, W+M$ and $W+F)$ the difference in total dry matter yields of rapeseed plants was insignificant at 25 and 85 DAS. Similar results were obtained in rapeseed yield also. Incase of micronutrient, significantly lower yield of dry matter per plant was produced by its application with weeding than with NPK fertilizers and FYM from flowering (25 DAS) to the beginning of maturation (70 DAS). However, at the maturation stage (85 DAS) where dry matter production per plant was mainly attributed to the deposition of siliqua, application of micronutrient with weeding practice $(1.519 \mathrm{~g} /$ plant) was only significantly lower than its combination with NPK fertilizers (3.449 g/plant in M + F). Similar trend was observed in yield. So, it can be mentioned that in comparison to the combination of micronutrient and weeding practice addition of NPK fertilizers to micronutrient was more effective than FYM.

In the combinations of three agronomic inputs significantly lower total dry matter per plant was recorded in the treatment without NPK fertilizers (FYM $+\mathrm{W}+\mathrm{M}$ ) as compared to others containing NPK fertilizers at all stages of growth and development (25 to $70 \mathrm{DAS}$ ). At 85 DAS it was insignificant only to the treatment containing NPK fertilizers (FYM + F + W) instead of micronutrient. Moreover, at the early stages (25 and 40 DAS) the total dry matter per plant produced in all combinations of three agronomic inputs containing NPK fertilizers were at par with each other. Similar effect was reflected on seed yield.

At all stages (25 to 85 DAS), the total dry matter per plant produced by the application of NPK fertilizers, FYM and micronutrient was remarkably higher than other combinations of three inputs containing NPK fertilizers. In the same way remarkably higher seed yield $(809.9 \mathrm{~kg} / \mathrm{ha})$ was produced in this combination (Basnet et al., 2004). In the combinations of three inputs containing NPK fertilizers, the seed yield declined according to the value of total dry matter per plant recorded at 85 DAS. This indicates that seed yield depends upon the accumulation of dry matter in rapeseed plants which magnitude is defined by the combination of different sources of nutrients supplied. Moreover, the correlation between total dry weight of the plants and rapeseed yield was significant ( $\mathrm{r}=0.976)$. Positive responses of NPK with FYM (Patel and Shelke, 1998), NPK with zinc and boron (Subbaiah and Mittra, 1996) and nitrogen with sulphur (Singh, 1999) in rapeseed and mustard yields have been reported. Finally, the total dry matter per plant produced in full package i.e. in the combination of all inputs $(F+M+W+F Y M)$ was at par with all combinations of three agronomic inputs 
including NPK fertilizers at the early (25 and 40 DAS) stages and at maturation (85 DAS). Such insignificant difference between these treatments was also observed in seed yield.

\section{CONCLUSIONS}

Balanced application of nutrients is necessary for better growth and development of each and every agricultural crop. Similar result was also found in rapeseed (Brassica campestris var toria) crop. On the basis of experiment conducted in rapeseed crop following conclusions were drawn.

1. As a single factor input, application of NPK fertilizers was the most effective in increasing leaf area and total dry matter per plant.

2. Exclusion of NPK fertilizers in the combination of three inputs significantly reduced the leaf area and total dry matter per plant where as its presence contributed to increase these parameters.

Finally, it can be concluded that for better growth and development of rapeseed crop in Chitwan valley a judicious application of inputs like NPK fertilizers, FYM and micronutrient into the soil is essential.

\section{ACKNOWLEDGEMENTS}

Seed Sector Support Project Nepal is gratefully acknowledged for the financial support. Mr. P. R. Bagale deserves thanks for his computer service.

\section{REFERENCES CITED}

Annual Report, 1998/99. Nepal Agriculture Research Council, National oilseed research program. Nawalpur, Sarlahi, Nepal. 66 p.

Arnon, I. 1972. Crop production in dry regions. Vol. 1. Leonard Hill. 598 p.

Basnet, B.B., K.B. Basnet, D.N. Yadav and S.P. Chand. 2004. Performance of rapeseed grown under different agronomic management in Chitwan. J. Inst. Agric. Anim. Sci. 25:11-16.

Bhatia, K.S. and K.K. Shukla.1982. Effect of continuous application of fertilizer and manure on some physical properties of eroded alluvial soils. J. Indian Soc. Soil Sci. 30(1): 33-36.

Chaudhary, N.K., R.C. Sharma, N.K. Mishra and K.R. Dahal.1993. Weed and fertilizer management in rapeseed and mustard. Research Report. IAAS, Rampur, Nepal (1985-91). pp. 527-31.

Ghimire, T.B., R.N. Chaudhary and S.P. Ray. 2000. Quantification of yield limiting constraints in toria production. Annual report, NORP, 2000/2001.61 p.

Joarrder, O.P., N.K. Paul and S.K. Ghosh.1959. Effect of irrigation and fertilizer on mustard. Expt. Agric. 15 (3): 299-302.

Kumar, A. and R.P. Singh. 1984. Paper presented at the annual oilseeds workshop, Sukhadia University Agril. Res. Station, 6-10 August 1984, Durgapur, India.

Kumar, R. 2001. Plant nutrient management studies in rapeseed and mustard. Ph.D. Thesis. Pantanagar University, Pantanagar, U.P. India.

Kumar, R.P. 1989. Oilseed, Brassica research in India. In oilseed crop proceeding, the meeting held at Pantanagar and Hyderabad, 4-7 Jan 1989 India.

Mishra, B. 2000. Oilseed research and development strategy in Nepal. In annual report NORP Nepal. Proceedings of $22^{\text {nd }}$ National Summer Workshop Nepal. NARC Khumaltar. pp. 108-111.

Patel, J.R. and V.B. Shelke. 1998. Effect of farm yard manure, phosphorus and sulphur of Indian Mustard (Brassica campestris). Indian J. Agron. 43(4): 713-17.

Rathore, P.S. 1999 Technique and management of field crops. Kalyani Publisher, New Delhi, India.

Reddy, T.Y. and G.H. Reddi. 1997. Principle of Agronomy. Kalyani Publication, New Delhi, India. 515p.

Singh, R.A. 1999. Nitrogen, Sulphur and calcium relationship in sustainable production of Indian mustard on denuded land. Indian J. Agron. 44(4): 820-825.

Sribastava, S.P and D.P Neupane. 2000. Long term fertility trial on maize-toria rotation at ARS, Rampur, Paper presented at the Regional Seminar Workshop, 27 to 29 March 2000. ARS, Lumle, Kaski, Nepal.

Subbaiah, G and B.N. Mittra. 1996. Effect of foliar spray of micronutrients on yield and oil content of Indian mustard (Brasasica juncea). Indian J. Agron. 41(1): 95-97. 